\title{
Managing by proxy: Organizational networks as institutional levers in evolving public good markets
}

\author{
Nicola Mountford \\ Maynooth University School of Business, Maynooth, Co. Kildare, Ireland
}

\section{A R T I C L E I N F O}

\section{Keywords:}

Public organizing

Market studies

Inter-organizational networks

Institutional theory

eHealth

\begin{abstract}
A B S T R A C T
Governments must ensure the sustainability of public goods in the face of evolutionary pressures: increasing private market power, escalating resource constraints and heightening consumer expectations. Research has demonstrated that organizational networks can be used to drive and shape markets but that institutionalized norms, values, and practices can block market change. I ask how governments can use networks to shape markets by proxy, complementing direct regulatory intervention. I draw on organizational networks literature, institutional theory, and longitudinal empirical evidence to examine government efforts to form a new interorganizational network to challenge institutional norms in Ireland's eHealth market. I identify three key processes that governments engage in when using networks to influence institutional change in evolving markets: empowering institutional challengers, reconciling competing institutional logics, and bridging policy and practice.
\end{abstract}

\section{Sustaining public good in an era of marketization}

"The Health Service Executive (HSE) would now like to invite tenders from suitably qualified companies/individuals to assist the Health Service Executive (HSE) with the setup, development and management of an eHealth Ecosystem for the Republic of Ireland." (ROI)

(Invitation to tender for an external eHealth Network (hereafter referred to as 'EcoNet') facilitator, March 2015, emphasis in the original)

As people live longer, many nations will see public healthcare expenditure increase to unsustainable level ${ }^{1,2}$. One response is eHealth, the use of technology to change the way care is delivered. This involves "a paradigm shift" (Mountford et al., 2016) in a context of multiple incompatible institutional logics (Dorado, 2005; Scott, 2000). A new market logic, based on the belief that markets will more efficiently allocate scarce resources (Djelic, 2006), is inserted into a context where a professional logic traditionally secured the clinician's decision-making and gate-keeping role (Reay \& Hinings, 2005).

Primary levels of organization can have institutional effects on secondary levels (Jepperson, 1991) and long-established norms, values, practices, and cultures can hinder institutional change (DiMaggio \& Powell, 1983). This means that societal institutions such as the role of the medical doctor, can have institutional effects on market context, affecting social structures such as market networks as well as institutional rules such as buyer and seller exchange roles (Aspers, 2011). These institutionalized social patterns are reproduced (and deviations sanctioned) "unless collective action blocks...the reproductive process" (Jepperson, 1991, p. 145). The role of institutional logics in processes of institutionalization and de-institutionalization has been examined in multiple contexts including healthcare (Reay \& Hinings, 2005; Zilber, 2002), as has the opportunity for institutional entrepreneurship created by overlapping logics, ambiguous identities, and multiple networks (Owen-Smith \& Powell, 2008). Whether the deliberate seeding of collective action through the creation of an inter-organizational network can block the reproductive process of one institutional order to create space for the re-institutionalization of another has not as yet been examined.

Organizational networks can be used to drive, create, and shape markets (e.g. Kjellberg, Azimont, \& Reid, 2015; Kjellberg \& Helgesson, 2006; Storbacka \& Nenonen, 2011b) and play a role in balancing institutional change and stability in evolving markets (Vargo, Wieland, \& Akaka, 2015). Networks have been seen as a locus for market innovation (Vargo et al., 2015), a forum for value co-creation (Möller, 2010; Rampersad, Quester, \& Troshani, 2010), and a strategic resource

\footnotetext{
This research did not receive any specific grant from funding agencies in the public, commercial, or not-for-profit sectors.

E-mail address: Nicola.mountford@mu.ie.

${ }^{1}$ The global population over 60 is expected to increase from 287 million in 2013 to $417 \mathrm{~m}$ in 2050 to $440 \mathrm{~m}$ in 2100 (http://esa.un.org/unpd/wpp/Documentation/ pdf/WPP2012_Volume-I_Comprehensive-Tables.pdf).

${ }^{2}$ European Commission (2012) Ageing Report: Economic and budgetary projections for the 27 EU Member States (2010-2060).
} 
(Möller, 2010; Möller \& Rajala, 2007). To-date, however, market studies have not seen the network as an institutional entrepreneur in its own right. In addition, how an actor should go about strategically influencing the network remains relatively black-boxed. In 2013 and 2014 Ireland's government published its objectives around eHealth market and network evolution in an eHealth strategy and commenced a tender process to establish an eHealth network to achieve these. In doing so it presented a unique opportunity to open up that black box. Drawing on organizational networks literature and neo-institutional theory, I chart how Ireland's government mobilizes a network towards feats of institutional entrepreneurship that shift institutionalized patterns of interaction. Specifically, I ask: "How do governments use organizational networks to influence the evolution of a market context and associated institutional changes?"

The healthcare market draws on actors from overlapping systems including production (firms/professionals from healthcare and technology, education, and research), diffusion (societal groups, public authorities), and use (patients and clinicians, patient representative bodies, professional bodies, care providers) (Geels, 2004). New eHealth technologies and pre-existing market technologies (such as those used in pricing, evaluation and matching) also act to reinforce or undermine the logics underpinning the market context. For the purposes of this paper, however, I focus on the categories of actors attended to in classic sociology, i.e. humans and human collectives.

Conceptually I respond to calls to further explore government/network relations (Arellano-Gault, Demortain, Rouillard, \& Thoenig, 2013; Mountford \& Geiger, 2019) by offering the concept of managing the market by proxy - forming organizational networks to effect or direct the evolution of a market. In doing so I position the network as a 'whole' market actor (Provan, Fish, \& Sydow, 2007) that proxies for powerful market actors who wish to complement hard power with softpower mechanisms. While legislation and regulation might create a fruitful environment for eHealth production (e.g. data protection and reimbursement), they will struggle to force use among patients or clinicians. I add to institutional entrepreneurship research (Maguire, Hardy, \& Lawrence, 2004; Rao, Morrill, \& Zald, 2000) following Aldrich (2011) to re-appropriate the term institutional entrepreneurship to "refer to the collective action of individuals and other entities that transform institutions" (p. 3). I describe a less heroic (Vaccaro \& Palazzo, 2015) and more team-based approach to institutional entrepreneurship. My process model opens this box in the context of the evolving market. I adapt theory developed in nascent and emerging market contexts (David, Sine, \& Haveman, 2013; Maguire et al., 2004; Santos \& Eisenhardt, 2009; Tracey \& Phillips, 2011) to the evolving market context which must contend with pre-existing, rather than absent, institutional foundations.

\section{Relationships between governments, networks, institutions, and the market}

Networks are the scaffolds and circulatory systems of a market (Owen-Smith \& Powell, 2008) and affect cognitive frames or institutional logics in change contexts (Beckert, 2010; Reay \& Hinings, 2005). To understand market change we must therefore examine the relationship between market context and both institutional logics and networks. Actors can influence market evolution within market context, institutional logic, or network spheres. For example, regulators operate at the market context level, institutional entrepreneurs at the logic level (Rao et al., 2000), and organizations may seek to shape networks (Rampersad et al., 2010; Storbacka \& Nenonen, 2011b). To identify the processes involved in the evolution of each sphere I therefore draw on literature from: organization studies as these relate to market organization and evolution (Ahrne, Aspers, \& Brunsson, 2015; Arellano-Gault et al., 2013); new institutional theory which deals with questions of agency in institutionalized contexts (DiMaggio \& Powell, 1983; Powell \& DiMaggio, 1991); and inter-organizational networks research, in particular how actors shape networks (Håkansson \& Ford, 2002; Möller, 2010; Rampersad et al., 2010).

\subsection{Markets, institutions, and institutional logics}

While economic, institutional, sociological, organizational, or geographic definitions of the 'market' each focus on a different aspect, I seek to capture all within the broader term of market context: market context is bounded by combinations of industry sector and geography although increasing transnationalism means that these are "largely in flux" (Djelic and Sahlin-Andersson, 2006, p. 7); processes of mutual adjustment and social relations result in the production/distribution of goods and the production/transformation of firms (Ahrne et al., 2015; Padgett \& Powell, 2012); and social structures and institutional rules (e.g. buyer/seller exchange roles, evaluation/pricing criteria) enable actors "to organize themselves, to compete and co-operate, and to exchange" (Aspers, 2011; Fligstein, 1996, p. 658).

Institutions are social structures that influence individual and organizational beliefs, actions, and feelings through "values, norms, rules, beliefs, and taken-for-granted assumptions" (Barley and Tolbert, 1997, p. 93; Lawrence, Suddaby, \& Leca, 2011). Neo-institutional theory folds agency into the stability and conformity of institutionalism (Dorado, 2005; Garud, Jain, \& Kumaraswamy, 2002; Greenwood, Suddaby, \& Hinings, 2002; Maguire et al., 2004). Field actors, through social processes and actions further develop, reinforce, or adapt institutions (Barley \& Tolbert, 1997). Thus institutions provide meaning, structure the attention of actors, signal appropriateness, and define the rules of play, but are also open to change (Vaccaro \& Palazzo, 2015). Alford and Friedland (1985) describe the practices and beliefs that shape individuals' actions as 'institutional logics': constituting an institutional order's "organizing principle" (Friedland \& Alford, 1991). Institutional logics have been tied to societal institutions present in the healthcare market including market, state, and professions (Thornton, 2002; Thornton, Ocasio, \& Lounsbury, 2012).

While the economist's ideal-type market is characterized by loose, impersonal relationships and shifting ties (Powell, 1990), real-world markets are regulated by social structure components including information transfer, collaborative problem-solving structures, and trust (Uzzi, 1997). Indeed, "even to compete, in a mutually non-destructive way, one needs at some level to trust one's competitors to comply with certain rules" (Gambetta, 1988, p. 215). Markets often contain "few cues, infrequent and irregular encounters, observables rather than talk and communication" (Araujo and Kjellberg, 2015, p. 69). Networks make encounters more regular and encourage communication, helping organizations to offer and interpret market cues. Shared socio-cognitive structures can thus be developed that will help to co-ordinate economic action and shape market context. Much of the research that examines agency and market context is focused on nascent markets - "unstructured settings with extreme ambiguity" that entrepreneurs claim, demarcate, and control, constructing firm and market boundaries (Santos and Eisenhardt, 2009, p. 644). In established but evolving market contexts, however, pre-existing institutions both enable and constrain. They reduce risk as "actions of others become more comprehensible and predictable" (Tracey and Phillips, 2011, p. 27), and act as self-policing conventions from which any deviation can be costly (Douglas, 1986). Where the formation of one market involves the evolution of multiple pre-existing markets this recursively shapes and is shaped by multiple wider market systems including their networks and institutions (Kjellberg \& Olson, 2017, p. 96).

I examine institutional logics and networks as foundation stones of the evolving market context. As actors employ and rely on each, they shape market contexts in the long term, while those market contexts constrain actors' choices in the short-term (Padgett \& Powell, 2012). Three key issues emerge in the inter-relationship between an evolving market context and its institutional foundations - legitimacy, trust, and market positions. Legitimacy involves a generalized perception that 
particular actions are correct, bounded by socially constructed institutional logics that shape norms, values, beliefs and definitions (Suchman, 1995). Trust goes beyond believing actors will rise above their own self-interest (Uzzi, 1997) or comply with the rules (Gambetta, 1988) where the network spans multiple communities with conflicting institutional logics. Rather it is trusting them to comply with the correct set of rules based on an appropriate institutional logic. Market positions in an evolving market are never future-proofed unlike established markets where established actors typically enterprise institutional adaptations (Sherer \& Lee, 2002). Institutional innovators come from, and must appeal to, a diverse range of actors (Maguire et al., 2004).

\subsection{Institutional logics as bridges between networks and market contexts}

Supra-organizational social patterns, based on institutional logics, provide meaning and organize both networks and market contexts (Friedland \& Alford, 1991; Thornton et al., 2012; Thornton \& Ocasio, 1999). These logics give market institutions force while conditioning relationships and network structures (Owen-Smith \& Powell, 2008). A pure 'market' logic, for example, believes that market mechanisms require only loose interpersonal relationships (Powell, 1990) rather than social relationships such as networks. Market logics are not, however, natural endpoints of market evolution, as markets are organized and reorganized by multiple actors in processes that integrate stakes, practices, norms, and values (Geiger, Harrison, Kjellberg, \& Mallard, 2014). Organizational networks offer forums where these can be surfaced and negotiated (Möller, 2010) and where multiple stakeholders can relate, problematize, and share issues (Geiger et al., 2014). I define inter-organizational networks as sets of actors (individuals, groups, and organizations) with recurring ties (resource, friendship, or informational) that gather to address a common concern or purpose (Oliver \& Ebers, 1998). My interpretation embraces a range of participants including use side participants and ecosystems (Autio \& Thomas, 2014).

Organizational relationships are traditionally constructed over time (Håkansson \& Ford, 2002) but in evolving markets new actors play crucial roles in networks even though relationships are young, resources not shared, knowledge partial and siloed, and understanding limited. Evolving markets require new relationships and new ways of working through relationships "to connect sets of capabilities within and across suppliers and customers' boundaries" (Araujo and Spring, 2006, p. 804). Diverse, inclusive networks can allow negotiation and calibration of ideas that may ultimately shape the market (Kjellberg \& Helgesson, 2006) as network activities and relationships allow actors to "make sense" of present and future network and market shapes (Gebauer, Paiola, \& Saccani, 2013; Möller, 2010). Logics can therefore be seen as a strategic resource (Venkataraman, Vermeulen, Raaijmakers, \& Mair, 2016) that can be used by and within networks "to cultivate new kinds of frames and categories" (Thornton et al., 2012, p. 182).

The literature leads us to conclude that networks can influence the evolution of institutional logics in three key ways. Sense-making at the network level allows new relationships to be formed, and assumptions, perceptions, knowledge, and resources shared (Möller, 2010). Synthesizing markets and industries within networks breaks, creates and maintains institutions underpinned by varying institutional logics. As previously disconnected actors are connected they shape the market context together (Finch \& Geiger, 2011), finding key points of overlap, negotiating common ground, and re-calibrating points of conflict (Geiger et al., 2014). Member profiling ensures a diverse network with multiple logics: identifying those that can contribute resources, issuing credible invitations, and understanding multiple motives (Håkansson \& Ford, 2002). Innovation requires diversity to generate new ideas (Clausen, 2014), and compatibility to relate, exchange and develop those ideas (Dawson, Young, Tu, \& Chongyi, 2014; Purchase, Olaru, \& Denize, 2014).

\subsection{Actors and agency in evolving market contexts}

Institutional entrepreneurs "spearhead collective attempts to infuse new beliefs, norms, and values into social structures." (Rao et al., 2000, pp. 238, 239). They often lead the co-design and co-development of new norms and structures within which actors can formulate responses to opportunities and threats. They socialise these structures, drive widespread use and acceptance, and champion their institutionalization. Network formation can be strategically directed (Matinheikki, Pesonen, Artto, \& Peltokorpi, 2017) while network management requires an ability to reduce uncertainty (Milliken, 1987; Rampersad et al., 2010) including the cultivation of "sets of conventions" that reduce or manage complexity (Loasby, 2002). Establishing such conventions in a market requires the institutionalization of exchange norms (Heide \& John, 1992): how information is shared, how products are evaluated, where exchange conversations occur, how products and services combine, and who pays/procures/evaluates/influences/decides. Taking on such a role, requires clout and commercial nous to frame an attractive network agenda and mobilize a diverse organizational cohort towards a common goal (Storbacka \& Nenonen, 2011a). This is often easier for a neutral actor (Garud et al., 2002) perhaps explaining why political, educational, social and cultural actors have become more influential in how new products and services make their way onto the market (Finch, Geiger, \& Reid, 2017; Möller, 2010). Governments often possess the legitimacy and political skill (Garud et al., 2002) to set the agenda for the network. This offers a unique opportunity to “...influence the relevant actors' sense-making processes and consequently the way they frame and interpret the business emergence" (Möller and Rajala, 2007, p. 905).

The literature demonstrates the strong connections between networks, institutional logics, and market context. It tells us that actors can enterprise new networks, and can impact on the development or evolution of institutions in feats of institutional entrepreneurship. Such profound change requires, however, multiple processes at multiple levels by powerful actors. While research has demonstrated that individual organizations might influence network structure and purpose, using the network to enterprise new versions of institutional logics has not yet been examined. How governments and networks should interact in order to bring about this shift in logics is a question that remains to be answered.

\section{Methodology: a longitudinal case study of network formation and management}

A case study approach facilitated deep understanding of the machinations and intentions of government in relation to both market context and the network (Mountford \& Kessie, 2017) addressing the 'how' element of the research question (Eisenhardt, 1989). The longitudinal approach recognized that market re-organization is an embedded process with a need to "conceptualize and study the interactive field within which changes are emerging over time" (Pettigrew et al., 2001, p. 688) and "understand and represent the experiences and actions of people as they encounter, engage, and live through situations" (Elliott, Fischer, \& Rennie, 1999). Naturalistic data was prioritized through ethnographic research methods such as observations and indepth interviews. A qualitative approach allowed the explorative range to develop new insights around market inter-relationships and connecting activities (Dubois \& Gadde, 2002), helped to "elucidate and explain complexity" (Neergard, 2007, p. 256), and suited the incremental nature of the market innovation (Geiger \& Finch, 2016).

Following the eHealth case raised my awareness of institutional logics and norms which interviewees spoke of as both blockers and potential facilitators of market evolution. This pointed towards new institutionalism as utilised within organizational studies to understand the cognitive and cultural (rather than rational-actor, legislation-based) activities in the case context (Powell \& DiMaggio, 1991). Government's 


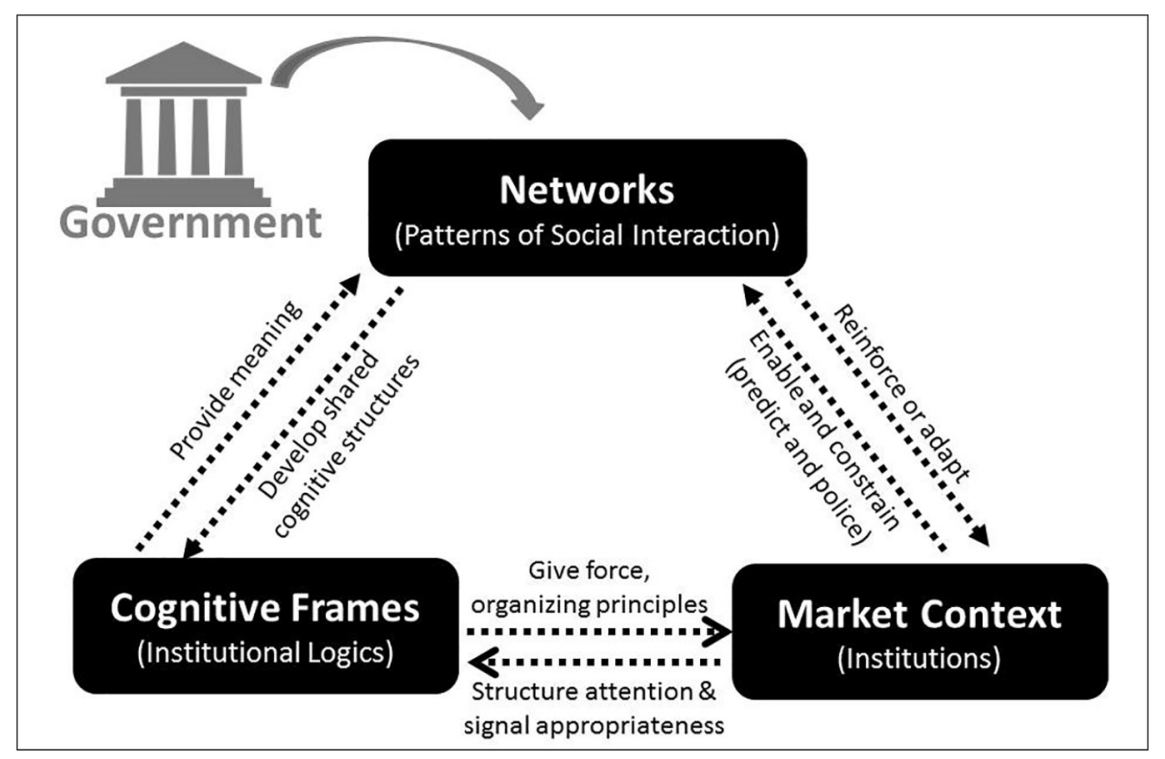

Fig. 1. Government's use of organizational networks to influence an evolving market context: analytical framework.

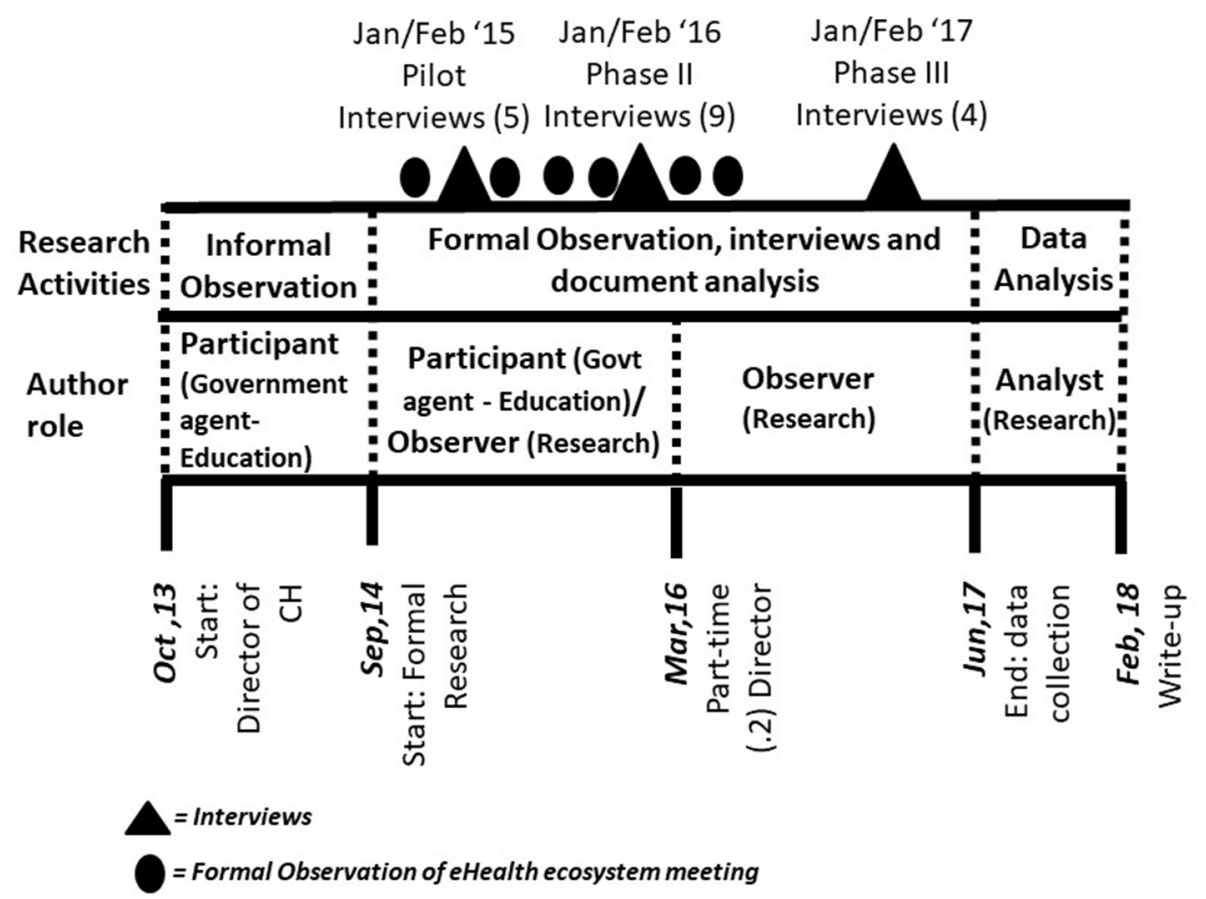

Fig. 2. Researcher roles and activities throughout the project.

strategic use of the network to accelerate the eHealth market directed me towards the market networks literature. I scrutinized the connections between network-constructing or shaping practices and attempted institutional change on the part of either government or network. I examined policy documents in the wider eHealth area such as Ireland's eHealth strategy, as well as funding calls for a health innovation hub and an applied research centre. I focused on the government activities and roles and cross-checked phenomena recorded against both literatures to avoid re-phrasing a concept already named elsewhere. The end result of this process was the development of an analytical framework as illustrated by Fig. 1 .

\subsection{Research context}

Healthcare is well documented as a market requiring evolution due to demographic change and resource pressures (Deloitte, 2018). The influence of institutions in healthcare has also been highlighted (e.g. Reay \& Hinings, 2005) as well as pressures for institutional change exerted by actors championing healthcare technology (Caulfield \& Donnelly, 2013). eHealth in Ireland reflects a market in documented evolution with a clear start-point: In 2013 government published its objectives around market and network evolution in an eHealth strategy. The tender process with which this paper opened offered a unique opportunity to track government efforts to influence a network for the purpose of impacting market evolution. EcoNet is a purpose-built interorganizational network whose underpinning logic was flagged from the outset by Ireland's government: enabling transactions and information exchange between key organizations, and effecting change in the eHealth market context. 


\subsection{Data collection}

Data collection focused on government processes that impacted the network, network activities that affected institutional logics, and the effect of institutional change on the market context. It therefore covered: government policy, promotion, and tender documents that mentioned EcoNet; government representatives' interactions with EcoNet stakeholders; network discussion of, and impacts on, institutions such as professional dominance; institutional logics apparent in actors' discourses and printed materials; and changes in market context and practices such as exchanges and partnering. Interviews, observations, and documentary analysis were all carried on throughout the life of the project (see Fig. 2 below). Intentions and designs laid out within a tender or policy document, for example as to the performance of the network as an instigator of collaborations, were checked against interviews and observations.

\subsubsection{Observations}

Within anthropology, ethnographers typically spend time with people to develop an understanding of the minute aspects of their life (Whitehead, 2005). I was immersed in the eHealth market for four years as Director of a university connected health research programme. Fig. 2 overviews my roles as researcher and participant over the lifetime of this project. I did carry with me a market logic having come from a previous role running a high-technology incubator programme. I therefore made particular efforts to hear and understand the concerns of those from non-market backgrounds such as clinicians, government, or patient representatives.

\subsubsection{Semi-structured interviews}

I conducted 18 semi-structured interviews with eHealth market actors (one interview per actor) including healthcare providers, government, technology firms, non-profit organizations, and academia (see Table 1). All informants demonstrated "thorough enculturation" and "current involvement" in the eHealth market (Spradley, 2016, p. 46). Interviews were usually performed face-to-face with a small number taking place over skype and averaged between $30 \mathrm{~min}$ and $1 \mathrm{~h} .12$ interviews were recorded and transcribed verbatim. For 6 interviews, where permission to record was not granted, copious field notes were taken instead. The interview protocol was designed to include questions intended to probe: 1) government actions in relation to eHealth as they impacted on the informant and/or their organization; 2) how their organizational network has changed as a result; and 3) how their

Table 1

Interviewee record.

\begin{tabular}{lll}
\hline & Sector & Title \\
\hline 1 & Technology & Head of eHealth \\
2 & Pharma & Project manager, eHealth \\
3 & Technology & CEO \\
4 & Technology & CEO \\
5 & Technology & CEO \\
6 & Non profit & COO \\
7 & Non profit & President \\
8 & Non profit & Network coordinator \\
9 & Government & Head of IT \\
10 & Government & Development advisor \\
11 & Government & Advisor, DG Connect European Union \\
12 & Healthcare & Chief information officer \\
13 & Patient representative & Ex CEO \\
& organization & \\
14 & Field expert & CEO, eHealth Research Institute \\
15 & Technology & VP, eHealth \\
16 & Academia & Research lead, eHealth research centre \\
17 & Healthcare & General practitioner, primary care \\
& & practice \\
18 & Healthcare & Head of IT, hospital \\
& &
\end{tabular}

Table 2

Documentary data gathered.

\begin{tabular}{ll} 
Documentary data & $\begin{array}{l}\text { Page } \\
\text { count }\end{array}$ \\
\hline Health innovation hub tender guide for applicants & 21 \\
Health innovation hub tender & 12 \\
Health innovation hub tender response doc & 15 \\
Applied Research for Connected Health (ARCH) call & 29 \\
ARCH Detailed Description of Needs (DDN) & 24 \\
eHealth strategy & 80 \\
Knowledge and information plan & 76 \\
eHealth Ministerial Conference 2013 Irish Presidency Declaration & 5 \\
Invitation to tender for the external support of an eHealth & 12 \\
$\quad$ Ecosystem Facilitator, Health Services Executive (HSE) Project & \\
$\quad$ 4948 & 15 \\
Tender response document HSE Project 4948 & 289 \\
Total page count & \\
\hline
\end{tabular}

experience of and perspective on the eHealth market may have changed. Questions were open and non-leading. While government documents referred to an intention to establish a 'network' or 'ecosystem' I specifically avoided use of the word 'network', preferring to let informants use their own terminology to describe their market relationships. For example, rather than asking what an organization's network looked like, I asked informants: "so how do you go about finding the right partners, or how do they find you?". Interviews do offer 'thick' descriptive data (Geertz, 2016) but are also vulnerable to retrospective sense-making (Eisenhardt \& Graebner, 2007). Interviews were therefore combined with other data collection points including diverse archival data, and observations.

\subsubsection{Documentary data}

I examined eHealth government documentation that mentioned inter-organizational networks including policy documents and government-issued invitations to tender. Such data offered insights into government intention and strategy in advance of network formation. In total, the database of documents ran to 289 pages (see Table 2).

\subsection{Data analysis}

I first immersed myself in the data to gain sufficient background, aided by my pre-existing knowledge of the field. I developed a descriptive list of network founding and managing activities as discussed by interviewees, found within documents, or observed at ecosystem meetings. I created detailed descriptions of these activities, which I used in the following analytical steps. I developed a theoretical list of network formation and management activities from the market networks literature. Merging the two lists, I formed an initial coding structure and applied this to the data using NVivo qualitative analysis software resulting in the first-order themes. As I attempted to apply each theme to impact on networks, institutional logics, or market context, groupings of codes began to emerge that were more relevant to each. Through an iterative process of cycling between data and literature, I developed first-level theoretical categories that encompassed the first-order themes. Finally I grouped these theoretical categories into three second-level aggregate categories: empowering institutional challengers, reconciling competing institutional logics, and bridging policy and practice (see Fig. 3 below). Reflexive note-keeping during data collection and analysis surfaced and questioned any potential bias.

\section{EcoNet - a government effort to create and legitimate a market management proxy}

\subsection{Phase I: developing an eHealth strategy}

In its 2013 EU presidency, Ireland presented a declaration on 


\begin{tabular}{|c|c|c|c|}
\hline Sample Quotes & \multirow{3}{*}{$\begin{array}{l}\text { First-order themes } \\
\begin{array}{c}\text { Belief in an individual or } \\
\text { organization in the face of fear } \\
\text { of unknown }\end{array} \\
\end{array}$} & $\begin{array}{l}\text { First-level } \\
\text { theoretical }\end{array}$ & \multirow{2}{*}{$\begin{array}{l}\text { Second-level } \\
\text { aggregate } \\
\text { categories }\end{array}$} \\
\hline $\begin{array}{l}\text { "So why do the companies talk to us? It's because we know about these things } \\
\text { from a semi-neutral perspective. So we can have the discussion with them and } \\
\text { we can guide them through it." (ROI110) }\end{array}$ & & categories & \\
\hline \multirow{2}{*}{$\begin{array}{l}\text { "But people follow people. People either believe in them or they don't. And no } \\
\text { matter what product or organisation that person is promoting you are not going } \\
\text { to get to that organisation if they think you are full of whatever." (ROI107) }\end{array}$} & & Trust & \multirow{4}{*}{$\begin{array}{l}\text { Empowering } \\
\text { Institutional } \\
\text { Challengers }\end{array}$} \\
\hline & Accepted as an authoritative & & \\
\hline $\begin{array}{l}\text { "Because we are selling to hospitals, we are becoming a hub for primary care." } \\
\text { (ROI105) }\end{array}$ & Are well connected to other & Ittmacy & \\
\hline & $\begin{array}{l}\text { Are well connected to other } \\
\text { organizations to their benefit }\end{array}$ & Positioning & \\
\hline $\begin{array}{l}\text { "eHealth systems are 'patient-centric' and involve the use of modern information } \\
\text { systems and technologies to integrate and coordinate the delivery of healthcare } \\
\text { to ensure improved patient outcomes, greater efficiencies of delivery, higher } \\
\text { levels of transparency and improved ease of access." (eHealth Strategy) }\end{array}$ & $\begin{array}{l}\text { Attempts to define, bound, or } \\
\text { explain eHealth }\end{array}$ & sense-makıng & \multirow{3}{*}{$\begin{array}{l}\text { Reconciling } \\
\text { competing } \\
\text { institutional } \\
\text { logics }\end{array}$} \\
\hline $\begin{array}{l}\text { "If it was any other sector we would have a challenge. When you add in } \\
\text { healthcare, we are really multiplying the challenge because technology and } \\
\text { health have never talked to each other very well." (ROI114) }\end{array}$ & $\begin{array}{l}\text { Dealing with the intersection } \\
\text { between healthcare and } \\
\text { technology }\end{array}$ & $\begin{array}{l}\text { Market } \\
\text { Synthesis }\end{array}$ & \\
\hline $\begin{array}{l}\text { So it's actually a massive ecosystem of companies that need to cooperate. } \\
\text { Because fundamentally, particularly as a technology provider, the technology } \\
\text { really is only one piece of it, it's that end-to-end service that people are looking } \\
\text { for. (ROI115) }\end{array}$ & $\begin{array}{l}\text { A wide range of organization } \\
\text { types are required to deliver } \\
\text { eHealth }\end{array}$ & $\begin{array}{l}\text { Member } \\
\text { Profiling }\end{array}$ & \\
\hline "We wanted something that would broaden the appeal outside of just the health & & & \\
\hline $\begin{array}{l}\text { domain. I think it's really important that those people who can act as, sponsors is } \\
\text { perhaps the wrong word..." (ROI109) }\end{array}$ & $\begin{array}{l}\text { Bridging/translating across } \\
\text { organizations/sectors }\end{array}$ & $\begin{array}{c}\text { Boundary- } \\
\text { spanning }\end{array}$ & \multirow{4}{*}{$\begin{array}{l}\text { Bridging } \\
\text { policy and } \\
\text { practice }\end{array}$} \\
\hline $\begin{array}{l}\text { We actively support the ecosystems with questions and help and guidance about } \\
\text { agendas, topics and linking and finding speakers and so on. (ROI106) }\end{array}$ & Influencing network & Agenda Setting & \\
\hline \multirow{2}{*}{$\begin{array}{l}\text { But a huge amount of energy from healthcare administrators and officials is in } \\
\text { dealing with institutions.They are dealing with hospital } X \text { and the Royal College of } \\
Y \text { and they are dealing with the National union of nurses. But the number of } \\
\text { players, and the complexity in healthcare, is just ginormous, and it is what's } \\
\text { holding back reform in healthcare. }\end{array}$} & format/focus & & \\
\hline & $\begin{array}{l}\text { Getting actors to rally around } \\
\text { the need for change }\end{array}$ & Mobilizing & \\
\hline
\end{tabular}

Fig. 3. Data structure for developing theoretical categorizations from raw data.

eHealth "aimed at prioritising the use of ICT in health among Member States to contribute to better, safer, sustainable and innovative healthcare systems..."3 In October 2013 I began a newly created job within Ireland's largest university managing its Connected Health programme. My role ran alongside a newly funded Connected Health applied research programme (ResearchNet) that worked with industry "to explore and evaluate potential connected health solutions for the global market". ${ }^{4}$ I believed that eHealth was high on political, academic, and business agendas holding great promise in a time of healthcare resource pressures. Towards the end of 2013 the Department of Health published Ireland's eHealth Strategy to "demonstrate how the individual citizen, the Irish healthcare delivery systems - both public and private - and the economy as a whole will benefit from eHealth." (Ireland's eHealth Strategy, 2014, p. 1). It reassured readers that eHealth is 'well documented' and based on a received set of 'principles and practices'. One enabler of eHealth within the strategy was the establishment of an eHealth ecosystem, " $a$ network that encompasses the key stakeholders involved in delivering eHealth deployments providing a common platform for interfacing and rapid access to information and transactions between them." (ibid, p. 42).

I spent the following year realizing that connecting eHealth's clinical, industry and academic stakeholders was no easy task and in September 2014 commenced a programme of study focused on this challenge. I became a participant observer (DeWalt \& DeWalt, 2010) taking copious field notes, analysing documents produced by the

\footnotetext{
${ }^{3}$ Press Release, Irish Presidency Announces Declaration on e-Health, 14.5.2013, www.health.gov.ie accessed 24/05/2017.

${ }^{4}$ ResearchNet flyer from October 2014.
}

multiple eHealth stakeholders and interviewing representatives from stakeholder organizations. At this point I conducted five pilot in-depth interviews with companies seeking to innovate and sell within the eHealth market (Interviewees $1-5$ in Table 1 ): a start-up selling to hospitals; a start-up selling to general practitioners (GPs); a multi-national pharmaceutical company designing new clinical trial methodologies; a multi-national company selling a device/service bundle direct to consumer; and a start-up selling direct to consumer. These interviews raised the presence of logics and norms as both blockers and facilitators. For example, many interviewees had begun their market journey at the GP's door only to find that GPs were not potential purchasers. Those experienced in selling into healthcare nevertheless still felt that GPs guard the market gate. As my pharma interviewee put it the GP "is the only way you get people to take things seriously" (ROI102).

These initial cases demonstrated that where companies had a market strategy it was based on prior experience of other markets. One of the two MNC companies interviewed used its vast salesforce to try every available channel, while the other invested heavily without any market assessment or conversation with potential customers. Consultants advising the start-ups and SMEs emphasised market research and exploiting the entrepreneur's experience and networks. Following this advice had without exception led to actors who were not interested in purchasing. Interviewees realised early that purchasing and decision making systems within Irish healthcare were not welcoming of innovative offerings. Co-creation therefore featured strongly with end users (clinicians and patients) shaping both product development and route to market. It seemed that the government strategy might be correct - a network approach might accelerate the growth of 
eHealth in Ireland.

In January 2014 the Hospital Inpatient Enquiry Scheme (HIPE), which provides information on patients in Irish hospitals, moved from the Economic and Social Research Institute (ESRI) into a new "Health Pricing Office". The goal was for money to follow the patient rather than being tied to an individual hospital. As one civil servant remarked, "if you are trying to change - to make managerial decisions on the back of that data - then it shouldn't be off over in the ESRI. And it no longer is - it is in the health pricing office - that tells you everything." (ROI110). The original location in a research institute reflected a view of HIPE data as "some bit of public health that you put alongside some census statistics and all the rest of it" (ROI110). Its new location, within the HSE, demonstrated a willingness to make managerial decisions on the back of that data.

Interviews and observations indicated that the market positions of hospitals and GPs remained fixed in the early stages of the strategy. Hospitals guarded the systems market in the same way that GPs protected the consumer market. As one start-up CEO puts it: "if the GP channel efforts were a dual carriageway, then the hospital channel was a boreen" (ROI105). Alliances targeted multiple segments where a single organization could not possibly afford to keep so many irons in the fire. One technology start-up had two such partnerships - the first with a private clinical organization to provide a direct-to-customer service; a second with an information systems provider to provide services to hospitals. Networks were also used to challenge the position of the GP as gatekeeper. One speaker at an EcoNet event recalled bringing patients into a GP meeting - listening to the patient describing their needs had made GPs more willing to share patient information.

\subsection{Phase II: establishing the network}

In the first quarter of 2015 the Department of Health set about formally establishing EcoNet, issuing an "Invitation to Tender for the External Support of an eHealth Ecosystem Facilitator". The tender document referred to "an eHealth Ecosystem comprising of academia, industry, hospital groups, primary care and social care centres ... with a specific remit of advancing the eHealth agenda." (Invitation to tender, HSE Project 4948). Interviewees accepted that new networks were needed but some didn't trust government to run a network in everyone's interest ("all [govt agency redacted] are interested in is bringing investment into Ireland and jobs into Ireland", ROI113). This was further complicated by the need for transparency in government procurement processes as eHealth involves large contracts for infrastructures. To avoid any suggestion that prior government/vendor relationships might influence decision-making and keep vendors at arm's length, government recruited an apparently-neutral network manager following government procurement guidelines. EcoNet launched in a Dublin hotel on the 29th of June 2015 where attendees discussed a potential ePharmacy programme. I became a member of EcoNet, attended and presented at meetings, and later became a member of its working group. The newly appointed non-profit EcoNet manager was also subject to distrust, being asked by other market actors "how do you make money out of this" (ROI107). He believed, however, that "people build relationships, then they build trust, then they start doing business" (ROI107). EcoNet sat alongside multiple eHealth-related networks operating in Ireland whose functions included "connecting" (ResearchNet), breaking down silos (EcoNet), building bridges (ProfNet), and facilitating innovation (InnoNet) (see Table 3). EcoNet is the only network that specifically includes patients as a membership category, reflecting the eHealth strategy's intent to define eHealth as patient-centred. Future EcoNet meetings would provide speaker opportunities for patients and position patient representative organizations as agenda-setters on the EcoNet working group. Innovative technology businesses were wooed with free

\footnotetext{
${ }^{5}$ A small laneway in rural Ireland.
}

exhibition space and pitching opportunities to encourage exposure to the ecosystem experience and messages.

Over the following year the ecosystem met 5 times (see Table 4). Meetings always opened with an update by a member of the HSE eHealth team as to progress on the eHealth agenda, key achievements and future plans. Meetings also included an update from the non-profit network manager highlighting successes in other eHealth ecosystems that they managed internationally. EcoNet's positive atmosphere towards the HSE eHealth team contrasted starkly with negative media, political, and general public discussion of the wider HSE. Over that same year 9289 complaints were made about HSE services, up $11 \%$ on the previous year. ${ }^{6}$ While interviewees expressed doubt as to the role and interests of other government agencies in the delivery of eHealth, I heard no such discussion around the HSE eHealth team. Whole meetings were dedicated to success stories such as "The Lighthouse Projects" meeting on the 1st March 2016, and the "12 Months On" meeting on the 29th of June 2016. At the former, the HSE's Chief Information Officer emphasised that using technology in healthcare will inevitably save lives before handing over to the keynote speaker -an entrepreneur, patient and carer. She spoke of the importance of stakeholder collaboration using examples from her experiences as a patient and carer to three children with complex conditions. Delegates were then given a brief overview of three successful, disease-specific Electronic Health Record (EHR) projects: epilepsy, haemophilia and bipolar disorder. All speakers emphasised that system integration is the key to success.

Department of Health and HSE staff focused network efforts on policy priorities through guidance on agendas, topics and speakers. Interviewees at the time spoke of eHealth as a fluid concept and of policymakers being slow to understand how eHealth could benefit the health system or the wider economy. EcoNet presenters spoke of a need for funding and structural change to properly implement eHealth and offered anecdotes to be brought back to actors' organizations and used to convince colleagues. For example, the CEO of a medical research non-profit group recalls convincing a group of senior clinicians to give patients direct access to their data. She had cited Estonia's citizen health portal to make her case and was in a position to paint a vivid picture of the system as she had seen it demonstrated by an Estonian health informatician at an eHealth network event. He had gone into his own record live on stage and shown attendees the information available to him as a citizen. eHealth champions, including myself, strove to convince their organizations to invest in eHealth innovation, network development, or product development. Within pharmaceutical multinationals, for example, eHealth teams 'cold-called' colleagues to raise awareness of eHealth, acting as 'internal eHealth consultants'.

Medical consumer firm ${ }^{7}$ interviewees expressed a need to change historical patient reliance on the clinician. These efforts were turboboosted by the presence of patient representatives at network events. At one EcoNet event a patient described her difficulty in seeking a diagnosis for her son - a process that took 14 years. She role-modelled active participation in the healthcare system while creating awareness of the patient experience for commercial and healthcare provider organizations. The eHealth strategy aims to place the patient at the centre of the Irish healthcare market. Including patient members and patient representative organizations in the network challenges clinical professional dominance. Indeed, the HSE themselves, having attended an EcoNet meeting where a patient spoke from the podium, realised that they should include patients in their discussions around clinical engagement for eHealth.

\footnotetext{
${ }^{6}$ Cullen, P., Health Service Complaints Rising, HSE Figures Show, The Irish Times, 9th June 2016, https://www.irishtimes.com/business/health-pharma/ health-service-complaints-rising-hse-figures-show-1.2677539, accessed 15th May, 2018.

${ }^{7}$ Firms that provide patients with products and services for self-assessment that may or may not combine with clinical input.
} 


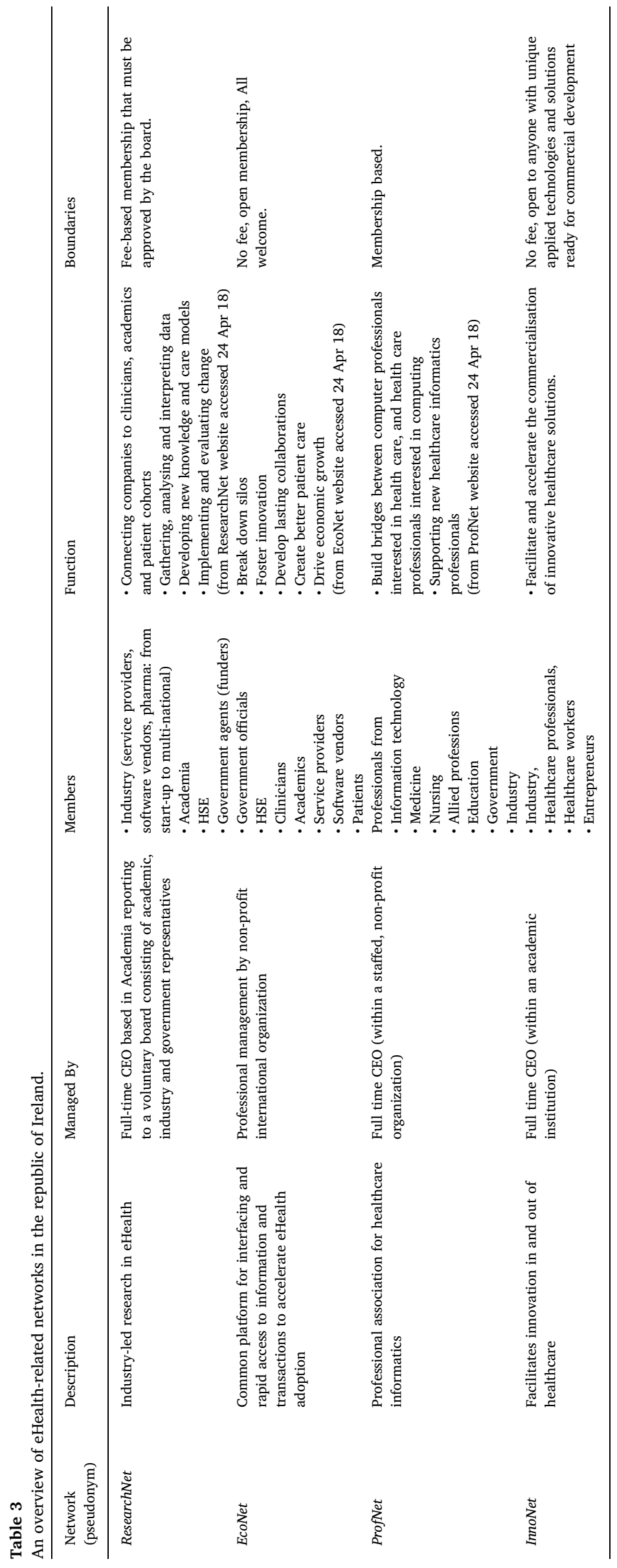


Table 4

EcoNet meeting topics.

\begin{tabular}{ll}
\hline Meeting topic & Date \\
\hline 12 Months On & 29th June 2016 \\
The Lighthouse Projects & 1st March 2016 \\
Electronic Health Records & 25th November 2015 \\
Clinical engagement & 18th September 2015 \\
ePharmacy & 29th June 2015 \\
\hline
\end{tabular}

The November 2015 EcoNet meeting discussed EHR implementation raising healthcare concerns (privacy and resource constraints) and technology challenges (integration and legacy systems). Clinicians defended professional doctor/patient confidentiality requirements; while healthcare managers sought population health and resource maximization. This is why one ICT service provider avoided stepping into clinical provision, instead forming partnerships with ready-made clinical organizations. EcoNet offered a forum where organizations could pool complementary skills and resources from different market segments. It educated members on institutions and regulatory regimes from other sectors with which they are unfamiliar. Different user perspectives also became clearer: for example, while hospital managers saw a unified EHR as a chance for service transformation, clinical users demanded best-of-breed EHRs to ensure quality of care.

As one Department of Health actor comments: "There are a lot of government plans and strategies on shelves and people do actually acknowledge that it is the strategy, but it doesn't necessarily work its way down into the agenda of everybody else at a senior level in the health system." (ROI109). While the ecosystem enjoyed its first year, ResearchNet's CEO was frustrated and couldn't "walk out to an industry park and find 10 [eHealth] companies - they are across everything from ICT to pharma to whatever" (ROI114). He struggled to balance marketlogic-based innovation and commercialisation metrics with care-logicbased patient engagement and pro bono public health research.

A repeating theme throughout the interviews concerned individuals/organizations who moved in multiple markets, seeing eHealth from multiple perspectives. A non-profit interviewee refers to one such HSE employee: "I don't even really see him as HSE." EcoNet's non-profit management echoes this need to not be pigeon-holed: “...we try to build this image of being neutral, we try to encourage communities." (ROI107). One patient representative organization epitomizes this ability to span market worlds, counting patients, scientists and pharma as members. Its CEO moves between academia, industry, and patient worlds representing patient interests and eventually takes on an agenda-setting role on the EcoNet working group.

\subsection{Phase III: network maturity}

Over 160 delegates attended EcoNet's one-year anniversary. Now meeting quarterly, it had become an established grouping of organizations and individuals including health professionals, medical educators, research students, nurses, general practitioners, industry leads, policymakers, patient group representatives, and service users. A government speaker celebrated eHealth's new role as a 'hub of widespread reform', not just replicating but reforming care and business processes. He cited as an example a laboratory software roll-out that had been jointly led by clinical and ICT staff, was available to all hospitals and primary care, was patient-centred, and was jointly provided by a variety of software, platform and service vendors. A service provider spoke of the new role of suppliers within the market as partners who can help healthcare providers understand what is available. An example was the national EHR business case co-developed by the HSE with input from all market stakeholders. The EcoNet agenda is now set by a working group of representatives from academia, the Department of Health, HSE, patient representative organizations, and industry. Spinout networks include the Council of Clinical Information Officers (over
170 clinicians, practitioners, academics and suppliers ${ }^{8}$ ), and One HealthTech (a network of local communities driving change in health technology through diversity). Other durable outcomes likely influenced by network activities include the changing role of the patient in Irish healthcare. The patient is more and more seen as an active participant in their own care evidenced by initiatives such as a pilot Patient Education Programme in Health Innovation led by the non-profit Irish Platform for Patient Organisations, Science \& Industry, with a number of Irish education partners (all EcoNet members). In a similar vein, Tallaght hospital, one of Ireland's largest acute teaching hospitals, has recently rolled out Ireland's first Patient Engagement mobile application.

\section{Managing-by-proxy: using the network to bring about shifts in institutional logics and market context}

Beckert (2010) shows how actors gather, transport and exploit resources in one market social structure and then use these to further their own goals in another. I find that powerful market actors can go one step further, enterprising market networks to alter the cognitive frames of other actors and challenge institutional structures.

Like nascent markets, our evolving market suffers from ambiguity that obscures the meaning and consequences of particular actions (Santos \& Eisenhardt, 2009). ResearchNet's CEO is unsure whether care or commercial metrics outputs will ultimately triumph, while multinationals send sales teams into multiple possible channels. In nascent markets such ambiguity arises due to unsettled market structure, unclear product definitions, and the absence of a dominant logic to guide decision-making (Santos \& Eisenhardt, 2009). Healthcare has pre-existing structures, product/service definitions, and dominant logics - but Ireland's government has determined a need to change these, basing its eHealth strategy on a market logic that emphasizes commercial, as well as the healthcare, benefits. But the prevailing (non market) structures, definitions, and logics are still present and actors must either set these aside, or allow new structures, definitions and logics to run parallel. This differs from a nascent market where actors write rules onto a relatively clean market slate and absent (or few) institutions create entrepreneurial opportunity for those sensing a positive risk/reward ratio (Tracey \& Phillips, 2011). Institutions do exist in the evolving market leaving few institutional voids for an entrepreneur to step into (Hensmans, 2003). Ireland's government creates institutional voids by supporting institutional challengers who are not yet institutional entrepreneurs. Institutional entrepreneurship is seen as a team sport with government running defence for the institutional challenger - lending them legitimacy, providing resources, and creating sense-making fora.

Ireland's government uses the network as a proxy to amplify its hard-power through soft power tactics that entrepreneurs employ to claim, demarcate, and control nascent markets (Santos \& Eisenhardt, 2009), particularly the cognitive, identity-shaping 'claiming' processes. EcoNet signals leadership and disseminates stories to raise awareness of eHealth. It borrows the cognitive model of the ecosystem from biology and business ecosystems (Moore, 1996) to indicate a sustainable set of relationships. Ireland's government uses the network as a relational demarcating mechanism to "gain clarity and support for their constructed market" (Santos and Eisenhardt, 2009, p. 654, emphasis added) in preference to a competing market that might be constructed by powerful firms unconcerned with public good. While Santos and Eisenhardt's entrepreneurs seek competitive dominance, Ireland's government establishes viable market roles for a wide range of suppliers, complementors, buyers, payers, and users. Controlling processes such as blocking entry or eliminating competing models are incompatible with government efforts to insert market logics into healthcare.

I identify three processes that form a framework for the use of

\footnotetext{
${ }^{8}$ www.ehealthireland.ie (accessed 24th May, 2018).
} 


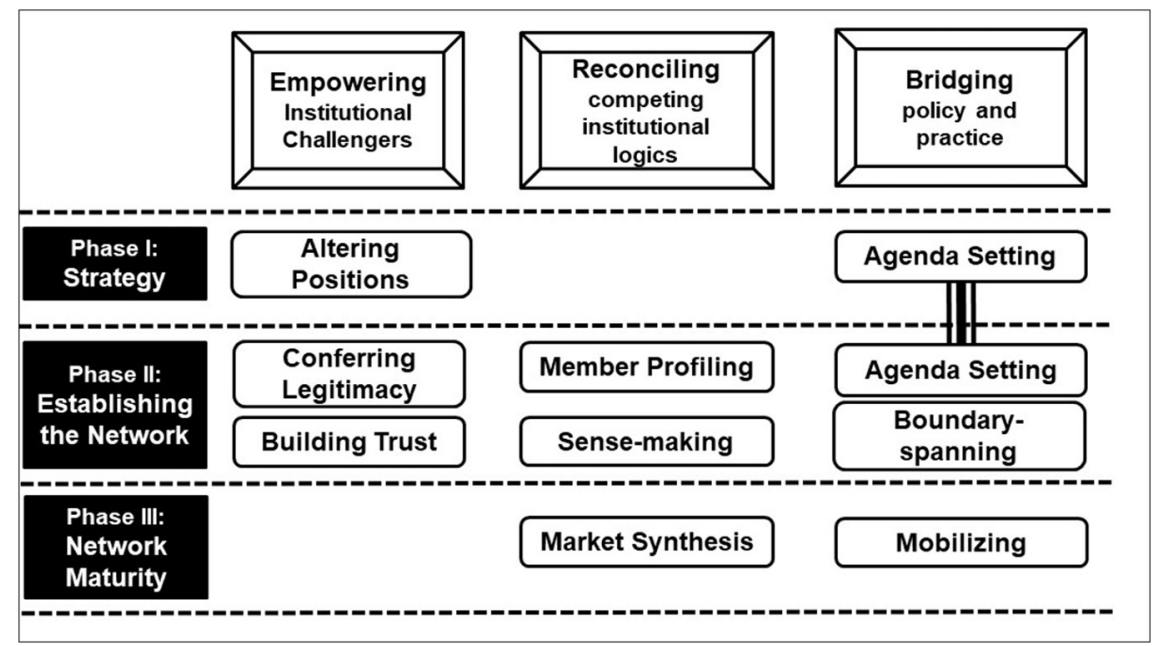

Fig. 4. A process map for managing-by-proxy using an inter-organizational network.

networks to manage market evolution by proxy (Fig. 4): 1) empowering institutional challengers, 2) reconciling competing market logics, and 3) bridging policy (intent) and practice (action).

\subsection{Empowering institutional challengers}

Government empowers individuals and organizations who challenge the institutional logics that hinder market evolution - case examples include patients, entrepreneurial insiders, innovative research centres - through three processes: building trust, conferring legitimacy, and reviewing network positions.

\subsubsection{Building trust}

Market evolution seeds distrust, threatening market information mechanisms, relationships, and positions and obscuring individual and organizational motives. In eHealth, information concerning the availability, quality and pricing of solutions and services is difficult to locate and interpret, doctors feel their patient relationship is threatened, and government agencies are not trusted to run a network in everyone's interest. Networks can, however, build trust by bringing market actors together regularly to build a new community (Tsai \& Ghoshal, 1998). EcoNet introduces new nodes, new ties between nodes, and new resulting patterns and relational structures (Ahuja, Soda, \& Zaheer, 2012) with organizations becoming allies against market ambiguity. The network can co-create a more holistic and representative vision of the market, learning to appreciate and trust each other's expertise, e.g. EcoNet's impact on patient roles in specifying and developing eHealth solutions.

\subsubsection{Conferring legitimacy}

Institutions confer legitimacy (Suchman, 1995) on existing market practices, threatening the emergence or survival of new practices. For example, many healthcare professionals require evidence from 'gold standard' randomized controlled trials before using eHealth for clinical diagnosis. This institutionalized dominance of profession (Reay \& Hinings, 2005) and the clinical trial process combine to block the legitimization of competing healthcare solutions that do not suit this proof process. Ireland's government seeks to overcome this barrier by attaching the legitimacy of other established institutions to eHealth, recruiting EcoNet management through an institutionalized tender process. The resulting apparent neutrality enhances network legitimacy as it is not seen to be a tool for any faction within eHealth. Careful agenda-setting and stage-management processes create a positive meeting atmosphere - an insulated microcosm in which the HSE eHealth team has more legitimacy than it does externally where it is one $\operatorname{cog}$ in a machine perceived to be creaking.

\subsubsection{Reviewing network positions}

Evolving markets come with pre-existing network positions that include access to resources and information, securing buyer and seller exchange roles (Aspers, 2011). For example, the gatekeeper positions of GPs and hospitals reflect the long-term professional logic underpinning the clinician's role as decision maker on behalf of the patient. Ireland's government allocated increased resources and information to institutional challengers compensating for the fact that it is typically established actors who enterprise institutional adaptations (Sherer \& Lee, 2002). The relocation of HIPE gives the HSE informational access that allows it to challenge institutionalized norms such as geographicallydistributed local hospitals. One interviewee claimed that this would have been impossible in the past as local politicians would have resisted comparative data that might show poor performance or limited need for their local hospital. This move may also reflect a shifting of the politician to a more peripheral network position in healthcare organization reinforcing the fact that no position is guaranteed in an evolving market. Institutional challengers must therefore cover their bases, facilitated by EcoNet's diverse range of actors (Maguire et al., 2004).

\subsection{Reconciling conflicting institutional logics}

Efforts by government, and in turn the network, to balance and resolve competing logics of market, state and profession appear across the data. These include processes of sense-making, market synthesis and member profiling.

\subsubsection{Sense-making}

Networking gives actors the tools to explain and support actions that may challenge pre-existing cognitive frames. Ireland's government uses terms that reflect medicine's emphasis on evidence and experience describing eHealth as 'well documented' and based on 'principles and practices'. This sense-making (Weick, 1995) takes place in individual organizations as well as at the network and market levels. At organizational level we see the eHealth strategy described as an internal as well as an external document - used to convince internal policy makers as well as external actors. At network level members query how network management profit from their role, as well as the conflicting drivers of the various parties (e.g. health/wealth; innovation/safety). At market level actors work to make sense of the new role of the consumer/patient. Spinning-out from EcoNet, for example, patient education modules are being designed that enable patients to input into industry and policy planning that will impact them. While marketizing 
healthcare might appear, on the face of it, to be un-civilizing behaviour (Callon, 2009), putting the patient at the centre of healthcare re-civilizes the market. These collective sense-making processes extend Weick's largely individual take on cognitive processing in the context of a concerned market (Geiger et al., 2014). Here, the patient concern, allows all stakeholder concerns to be related to the patient as system centre, all troubles or problems to be contextualized by patient benefit, and the influence of specific concerns to be heightened or prioritized through attachment to the patient cause.

\subsubsection{Market synthesis}

Public good market contexts will certainly span multiple institutional logics and may span multiple established industries. The eHealth strategy refers to commercial and healthcare gains while eHealth includes healthcare delivery, consumer electronics, and information and communication technology. Market synthesis in an evolving market is, however, likely to be a process of intermingling, rather than merging or re-forming organizations in its early years. Although eHealth does require both technical and clinical competence, one ICT service provider says that they would not consider clinical provision due to the complexity of the services involved, the training and qualifications required, and the fact that they can partner with existing clinical organizations. The network offers a forum that bridges industries and logics allowing differences to be surfaced and negotiated (Möller, 2010) while stakes, practices, norms, and values can be integrated (Geiger et al., 2014). For example in the EHR EcoNet meeting, resource and legacy system discussions speak to market logics around cost/benefit, while privacy concerns revolve around professional logics. The common concern (an EHR for Ireland) brings actors together across industry and logic divides to share information (Oliver \& Ebers, 1998), building a synthesis of industry and logic to shape a new market context in which they can exchange products and services (Finch \& Geiger, 2011).

\subsubsection{Member profiling}

Where networks bring together organizations with different perspectives - different sectors, sizes, and stages - they can be more innovative (Clausen, 2014). Government's public/private reach and innovation funding mechanisms position it to deliver the density and multiplexity of relationships required for a successful new network (Achrol, 1997). Its privileged access to all sectors and players ensures actor heterogeneity, increasing links and learning while forming more homogenous, common interest subnetworks that facilitate information exchange and communication (Nissen, Evald, \& Clarke, 2014; Purchase et al., 2014). The right membership profile - a balance of perspectives, resources, competencies and experience - avoids a lopsided network. Thus patient organizations in EcoNet challenged both clinical professional dominance and prevailing market-based management logics.

\subsection{Bridging policy and practice through leaders and lighthouse projects}

Changing a market context requires translation of policy (such as an eHealth strategy) into action. Making the envisaged institutional evolution a market reality requires processes of boundary spanning, agenda setting and mobilizing.

\subsubsection{Boundary spanning}

Networks are used to identify, bring together, and guide members of a value chain that might develop evolving market solutions. EcoNet acts as a bridge spanning policy and practice, looking up to government and down to its grassroots members for network objectives and strategy. But pre-existing institutions are strong. The life-and-death nature of healthcare can mitigate against longer-term policy change such as investment in future-oriented eHealth infrastructure. These situations are far from the "unstructured settings with extreme ambiguity" discussed by Santos and Eisenhardt (2009) when they speak of the construction of market boundaries. Even those empowered by professional logics (such as senior clinicians) need assistance to craft convincing messages that challenge existing healthcare policy and practice. Boundary spanners are required to lead the charge across both industry and logic boundaries, building new relationships and new ways of working within relationships (Araujo and Spring, 2006, p. 804). They are often peripheral in their own organizations or industries and thus perceived as more understanding of other actors' norms and perspectives. In describing an excellent boundary spanner one interviewee used the phrase "I don't even see him as HSE", demonstrating that need to almost divorce oneself from one's organizational roots to convince others.

\subsubsection{Agenda setting}

Setting a new market agenda would be resource-intensive considering the dispersed nature of actors and the inability to identify dominant positions (Storbacka \& Nenonen, 2011a) - "the number of players, and the complexity in healthcare, is just ginormous, and it is what's holding back reform in healthcare." (ROI109). Network agendas are, however, easier to influence and may percolate through to the market. EcoNet offers a single space for Ireland's government to engage with all the relevant actors. The network becomes a neutral actor that can be focused, using government's legitimacy and political skill, on key policy areas (Garud et al., 2002), evidenced by EcoNet's ePharmacy, clinical engagement, and EHR meetings. Government, through its network proxy, frames and interprets the emergence of a new eHealth market (Möller \& Rajala, 2007).

\subsubsection{Mobilizing}

In many states government's support of indigenous enterprise, together with its experience of navigating institutions, can position it to direct network formation for market evolution (Matinheikki et al., 2017). Government has the connections and finance to seed entrepreneurial coalitions of traditionally non powerful actors to drive bottom up institutional change. In eHealth, government policy makers recognise that policy implementation requires mobilization of all stakeholder groups. The strategy sets out a vision against which future change can be measured and doubts as to policy priorities resolved. Given the innovative nature of eHealth products and services, established organizations often require a sales pitch to reduce the associated uncertainty (Milliken, 1987; Rampersad et al., 2010). EcoNet rallies an army of eHealth champions, offering it a menu of success stories, scientific data, and potential knowledge and implementation partners that can be used to overcome such doubts, challenges and inertia. These success stories establish new exchange norms with regard to information, evaluation, and combinations of products and services (Heide \& John, 1992). They arm champions who in turn spearhead the infusion of the new beliefs, norms and values required to mobilize new eHealth social structures (Rao et al., 2000).

\subsection{Conceptual contributions}

How governments and networks should interact to bring about the shifts in institutional logics necessary to sustain public good markets remains unanswered by extant literature (Arellano-Gault et al., 2013). I add to literature on institutional entrepreneurship (Maguire et al., 2004; Rao et al., 2000), demonstrating that the network can act as a proxy actor for government to complement their hard power with softpower mechanisms. I describe a less heroic (Vaccaro \& Palazzo, 2015) and more team-based approach to institutional entrepreneurship, distinguishing a new category of actor within institutional entrepreneurship - the institutional challenger. Government empowers institutional challengers by conferring vital legitimacy (Rosa, Porac, Runser-Spanjol, \& Saxon, 1999) at the network level, by encouraging and modelling trust in key individuals or organizations, and by consciously altering the positioning of organizations within the network.

While acknowledging the socio-technical nature of the market, I confine my study to the "socio" element of that market. While I 
understand that this renders it potentially less complete horizontally, I believe that I compensate for this vertically as I track the sociological effects from the institutional change back through the network to government. That individual organizations might influence network structure and purpose has been established, but using the network to intentionally change institutional logics at the market level offers a new perspective on such market-shaping activities. I add to research that positions the network as a potential innovation and value co-creation forum or market-shaping tool (Möller, 2010; Möller \& Rajala, 2007; Rampersad et al., 2010; Vargo et al., 2015). Such discussions are predominantly conceptual rather than empirical: the ecosystem remains a "rather loosely defined and versatile metaphor" (Autio and Thomas, 2014, p. 204); and the processes by which one might influence networks remain relatively black-boxed. I clearly stake out a role for the whole network (Kilduff \& Tsai, 2003) as market actor offering a process model for market management by proxy in evolving markets that details three high level and nine sub-level processes that constitute an effort by one powerful actor to manage a market evolution by proxy.

In addressing these gaps, I distinguish the context of the evolving market from that of the nascent market. Borrowing from theory developed in nascent market contexts (such as Maguire et al., 2004; Santos \& Eisenhardt, 2009; Tracey \& Phillips, 2011; David et al., 2013), I apply these in the new context of the evolving market. Here all three of Beckert's structures: social networks, institutions and cognitive frames; are already in situ creating a pre-existing institutional foundation on which an evolved market version must be built. I find that while elements of theory developed in emerging markets (such as Santos \& Eisenhardt's claiming and demarcating processes) are present in the evolving market context they require prior processes of challenging existing institutions and reconciling conflicting institutional logics. This tallies with the experience of Kjellberg and Olson (2017) that apparently new markets can be significantly influenced by their interrelations with existing markets. My process model adds detail as to how the interorganizational network influences market inter-relation, formation, and bounding processes.

\subsection{Implications for practice}

I develop a framework for governments responding to evolutionary pressures that require both change and continuity, highlighting the importance of network formation and management to influence the trajectory of market evolution. My process model offers advice for policy makers as to how to focus government efforts at different stages of network maturity in the context of one public good market: healthcare. A focus on three key processes: empowering institutional challengers, reconciling competing market logics, and bridging policy (intent) and practice (action), will allow government to best harness the actors' market management capabilities and resources. While empowerment features strongly in the early stages of strategy and network conception, reconciliation and bridging activities become more important as the network matures. Companies navigating market evolution should engage with government, encouraging government to use its deeper pockets and wider connections to establish networks sympathetic to their desired market version. Companies should work with governments to influence agendas and sense-making frames. They should ensure that they and their preferred customers and collaborators are included in network member profiles.

\section{Conclusion}

I set out to understand how governments use networks to influence evolution at multiple levels: network, institutions, and market. I develop the concept of 'management by proxy' - a bottom up, non-legislative approach to market making and shaping by government and demonstrate how inter-organizational networks may bridge and synthesize constituent markets in one highly institutionalized context - healthcare. Further research is needed to see how these findings might translate into differently constituted public good markets such as energy, communications or education. I find that powerful market actors (such as governments) can go beyond gathering resources from an existing network, rather manufacturing and managing the network to alter cognitive frames and challenge institutional structures. This study focuses on one type of actor (government) in one territory (Ireland). Across the globe the role of government in the provision of healthcare services is highly diverse offering opportunities for future studies into the effect of market roles on an actor's ability to manage by proxy. Finally, I develop a process model for managing-by-proxy in the context of a nation state's healthcare market. Whether or not this model could be applied by individual actors in narrower contexts might well be the subject of future organizational network studies.

\section{Acknowledgements}

The author gratefully acknowledges the reading and revision suggestions by Susi Geiger to an earlier draft and the assistance of the ECHAlliance in data collection. The author alone is responsible for all limitations and errors that may relate to the study and the paper.

\section{References}

Achrol, R. S. (1997). Changes in the theory of interorganizational relations in marketing: Toward a network paradigm. Journal of the Academy of Marketing Science, 25(1), 56-71.

Ahrne, G., Aspers, P., \& Brunsson, N. (2015). The organization of markets. Organization Studies, 36(1), 7-27.

Ahuja, G., Soda, G., \& Zaheer, A. (2012). The genesis and dynamics of organizational networks. Organization Science, 23(2), 434-448.

Aldrich, H. E. (2011). Heroes, villains, and fools: Institutional entrepreneurship, NOT institutional entrepreneurs. Entrepreneurship Research Journal, 1(2), 2.

Alford, R., \& Friedland, R. (1985). Powers of theory: Capitalism, the state, and democracy. Cambridge: Cambridge University Press.

Araujo, L., \& Kjellberg, H. (2015). Forming cognitions by investing in a form: Frequent Flyer Programs in US air travel post-deregulation (1981-1991). Industrial Marketing Management, 48, 68-78.

Araujo, L., \& Spring, M. (2006). Services, products, and the institutional structure of production. Industrial Marketing Management, 35(7), 797-805.

Arellano-Gault, D., Demortain, D., Rouillard, C., \& Thoenig, J.-C. (2013). Bringing public organization and organizing back in. Organization Studies, 34(2), 145-167.

Aspers, P. (2011). Markets. Cambridge: Polity.

Autio, E., \& Thomas, L. D. W. (2014). Innovation ecosystems. Implications for innovation management? In M. Dodgson, D. M. Gann, \& N. Phillips (Eds.). The Oxford handbook of innovation management (pp. 204). Oxford: Oxford University Press.

Barley, S. R., \& Tolbert, P. S. (1997). Institutionalization and structuration: Studying the links between action and institution. Organization Studies, 18(1), 93-117.

Beckert, J. (2010). How do fields change? The interrelations of institutions, networks, and cognition in the dynamics of markets. Organization Studies, 31(5), 605-627.

Callon, M. (2009). Civilizing markets: Carbon trading between in vitro and in vivo experiments. Accounting, Organizations and Society, 34(3), 535-548.

Caulfield, B. M., \& Donnelly, S. C. (2013). What is Connected Health and why will it change your practice? Quarterly Journal of Medicine, 106(8), 703-707.

Clausen, T. H. (2014). The role of institutional arbitrage in the search for product innovation: Firm level evidence from Norway. Industrial Marketing Management, 43(3), 392-399.

David, R. J., Sine, W. D., \& Haveman, H. A. (2013). Seizing opportunity in emerging fields: How institutional entrepreneurs legitimated the professional form of management consulting. Organization Science, 24(2), 356-377.

Dawson, B. K., Young, L., Tu, C. L., \& Chongyi, F. (2014). Co-innovation in networks of resources - A case study in the Chinese exhibition industry. Industrial Marketing Management, 43(3), 496-503.

Deloitte (2018). Global health care outlook. The evolution of smart health care.

DeWalt, K., \& DeWalt, B. R. (2010). Participant observation: A guide for fieldworkers. Rowman Altamira.

DiMaggio, P. J., \& Powell, W. W. (1983). The iron cage revisited: Institutional isomorphism and collective rationality in organizational fields. American Sociological Review, 48(6), 147.

Djelic, M. L., \& Sahlin-Andersson, K. (Eds.). (2006). Transnational governance. Cambridge: Cambridge University Press.

Djelic, M.-L. (2006). Marketization: From intellectual agenda to global policy making. In M.-L. Djelic, \& K. Sahlin-Andersson (Eds.). Transnational governance. Cambridge: Cambridge University Press.

Dorado, S. (2005). Institutional entrepreneurship, partaking, and convening. Organization Studies, 26(3), 385-414.

Douglas, M. (1986). How institutions think. Syracuse University Press.

Dubois, A., \& Gadde, L.-E. (2002). Systematic combining: An abductive approach to case 
research. Journal of Business Research, 55(7), 553-560.

Eisenhardt, K. M. (1989). Building theories from case study research. The Academy of Management Review, 14(4), 532-550.

Eisenhardt, K. M., \& Graebner, M. E. (2007). Theory building from cases: Opportunities and challenges. The Academy of Management Journal, 50(1), 25-32.

Elliott, R., Fischer, C. T., \& Rennie, D. L. (1999). Evolving guidelines for publication of qualitative research studies in psychology and related fields. British Journal of Clinical Psychology, 38(3), 215-229.

Finch, J., \& Geiger, S. (2011). Constructing and contesting markets through the market object. Industrial Marketing Management, 40(6), 899-906.

Finch, J., Geiger, S., \& Reid, E. (2017). Captured by technology? How material agency sustains interaction between regulators and industry actors. Research Policy, 46(1), $160-170$.

Fligstein, N. (1996). Markets as politics: A political-cultural approach to market institutions. American Sociological Review, 61(4), 656-673.

Friedland, R., \& Alford, R. R. (1991). Bringing society back. Symbols, practices and institutional contradictions.

Gambetta, D. (1988). Trust: Making and breaking cooperative relations. Vol. 52. Blackwell.

Garud, R., Jain, S., \& Kumaraswamy, A. (2002). Institutional entrepreneurship in the sponsorship of common technological standards: The case of Sun Microsystems and Java. The Academy of Management Journal, 45(1), 196-214.

Gebauer, H., Paiola, M., \& Saccani, N. (2013). Characterizing service networks for moving from products to solutions. Industrial Marketing Management, 42(1), 31-46.

Geels, F. W. (2004). From sectoral systems of innovation to socio-technical systems: Insights about dynamics and change from sociology and institutional theory. Research Policy, 33(6), 897-920.

Geertz, C. (2016). The interpretation of cultures (text only). HarperCollins Publishers.

Geiger, S., Harrison, D., Kjellberg, H., \& Mallard, A. (2014). Being concerned about markets. In S. Geiger, D. Harrison, H. Kjellberg, \& A. Mallard (Eds.). Concerned markets. Cheltenham, UK: Edward Elgar Publishing Ltd.

Geiger, S., \& Finch, J. (2016). Making incremental innovation tradable in industrial service settings. Journal of Business Research, 69(7), 2463-2470.

Greenwood, R., Suddaby, R., \& Hinings, C. R. (2002). Theorizing change: The role of professional associations in the transformation of institutionalized fields. The Academy of Management Journal, 45(1), 58-80.

Håkansson, H., \& Ford, D. (2002). How should companies interact in business networks? Journal of Business Research, 55(2), 133-139.

Heide, J. B., \& John, G. (1992). Do norms matter in marketing relationships? Journal of Marketing, 56(2), 32-44.

Hensmans, M. (2003). Social movement organizations: A metaphor for strategic actors in institutional fields. Organization Studies, 24(3), 355-381.

Jepperson, R. L. (1991). Institutions, institutional effects, and institutionalism. In W. W. Powell, \& P. J. DiMaggio (Eds.). The new institutionalism in organizational analysis. Chicago, USA: University of Chicago Press.

Kilduff, M., \& Tsai, W. (2003). Social networks and organizations. Thousand Oaks, CA: Sage.

Kjellberg, H., Azimont, F., \& Reid, E. (2015). Market innovation processes: Balancing stability and change. Industrial Marketing Management, 44, 4-12.

Kjellberg, H., \& Helgesson, C.-F. (2006). Multiple versions of markets: Multiplicity and performativity in market practice. Industrial Marketing Management, 35(7), 839-855.

Kjellberg, H., \& Olson, D. (2017). Joint markets: How adjacent markets influence the formation of regulated markets. Marketing Theory, 17(1), 95-123.

Lawrence, T., Suddaby, R., \& Leca, B. (2011). Institutional work: Refocusing institutional studies of organization. Journal of Management Inquiry, 20(1), 52-58.

Loasby, B. J. (2002). The evolution of knowledge: Beyond the biological model. Research Policy, 31(8), 1227-1239.

Maguire, S., Hardy, C., \& Lawrence, T. B. (2004). Institutional entrepreneurship in emerging fields: HIV/AIDS treatment advocacy in Canada. The Academy of Management Journal, 47(5), 657-679.

Matinheikki, J., Pesonen, T., Artto, K., \& Peltokorpi, A. (2017). New value creation in business networks: The role of collective action in constructing system-level goals. Industrial Marketing Management, 67, 122-133.

Milliken, F. J. (1987). 3 types of perceived uncertainty about the environment - State, effect, and response uncertainty. Academy of Management Review, 12(1), 133-143.

Möller, K. (2010). Sense-making and agenda construction in emerging business networks - How to direct radical innovation. Industrial Marketing Management, 39(3), 361-371.

Möller, K., \& Rajala, A. (2007). Rise of strategic nets - New modes of value creation. Industrial Marketing Management, 36(7), 895-908.

Moore, J. F. (1996). The death of competition: Leadership and strategy in the age of business ecosystems. New York: Harper Business.

Mountford, N., \& Kessie, T. (2017). Towards a more holistic understanding of whole organizational networks: Anthropological approaches in evolving markets. The Electronic Journal of Business Research Methods, 15(2), 74-84.

Mountford, N., Kessie, T., Quinlan, M., Maher, R., Smolders, R., et al. (2016). Connected Health in Europe: Where are we today?

Mountford, N., \& Geiger, S. (2019). Duos and duels in field evolution: How governments and Interorganizational networks relate. Organization Studies, $O(0)$ (0170840618789210).

Neergard, H. (2007). Sampling in entrepreneurial settings. Handbook of qualitative research methods in entrepreneurship. Cheltenham: Edward Elgar.

Nissen, H. A., Evald, M. R., \& Clarke, A. H. (2014). Knowledge sharing in heterogeneous teams through collaboration and cooperation: Exemplified through Public-PrivateInnovation partnerships. Industrial Marketing Management, 43(3), 473-482.

Oliver, A. L., \& Ebers, M. (1998). Networking network studies: An analysis of conceptual configurations in the study of inter-organizational relationships. Organization Studies, 19(4), 549-583.

Owen-Smith, J., \& Powell, W. W. (2008). The SAGE handbook of organizational institutionalism.

Padgett, J. F., \& Powell, W. W. (2012). The problem of emergence.

Pettigrew, A. M., Woodman, R. W., \& Cameron, K. S. (2001). Studying organizational change and development: Challenges for future research. The Academy of Management Journal, 44(4), 697-713.

Powell, W. W. (1990). Neither markets nor hierarchy. Network forms of organization. Research in Organizational Behavior, 12, 295-336.

Powell, W. W., \& DiMaggio, P. J. (Eds.). (1991). The new institutionalism in organizational analysis. Chicago and London: University of Chicago Press.

Provan, K. G., Fish, A., \& Sydow, J. (2007). Interorganizational networks at the network level: A review of the empirical literature on whole networks. Journal of Management 33(3), 479-516.

Purchase, S., Olaru, D., \& Denize, S. (2014). Innovation network trajectories and changes in resource bundles. Industrial Marketing Management, 43(3), 448-459.

Rampersad, G., Quester, P., \& Troshani, I. (2010). Managing innovation networks: Exploratory evidence from ICT, biotechnology and nanotechnology networks. Industrial Marketing Management, 39(5), 793-805.

Rao, H., Morrill, C., \& Zald, M. N. (2000). Power plays: How social movements and collective action create new organizational forms. Research in Organizational Behavior, $22,237-281$.

Reay, T., \& Hinings, C. R. (2005). The recomposition of an organizational field: Health care in Alberta. Organization Studies, 26(3), 351-384.

Rosa, J. A., Porac, J. F., Runser-Spanjol, J., \& Saxon, M. S. (1999). Sociocognitive dynamics in a product market. Journal of Marketing, 63, 64-77.

Santos, F. M., \& Eisenhardt, K. M. (2009). Constructing markets and shaping boundaries: Entrepreneurial power in nascent fields. The Academy of Management Journal, 52(4), 643-671.

Scott, W. R. (2000). Institutional change and healthcare organizations: From professional dominance to managed care. University of Chicago Press.

Sherer, P. D., \& Lee, K. (2002). Institutional change in large law firms: A resource dependency and institutional perspective. The Academy of Management Journal, 45(1), $102-119$.

Spradley, J. (2016). The ethnographic interview. Illinois, USA: Waveland Press Inc.

Storbacka, K., \& Nenonen, S. (2011a). Markets as configurations. European Journal of Marketing, 45(1-2), 241-258.

Storbacka, K., \& Nenonen, S. (2011b). Scripting markets: From value propositions to market propositions. Industrial Marketing Management, 40(2), 255-266.

Suchman, M. C. (1995). Managing legitimacy: Strategic and institutional approaches. The Academy of Management Review, 20(3), 571-610.

Thornton, P. H. (2002). The rise of the corporation in a craft industry: Conflict and conformity in institutional logics. Academy of Management Journal, 45(1), 81-101.

Thornton, P. H., \& Ocasio, W. (1999). Institutional logics and the historical contingency of power in organizations: Executive succession in the higher education publishing industry, 1958-1990. American Journal of Sociology, 105(3), 801-843.

Thornton, P. H., Ocasio, W., \& Lounsbury, M. (2012). The institutional logics perspective: $A$ new approach to culture, structure, and process. Oxford University Press on Demand.

Tracey, P., \& Phillips, N. (2011). Entrepreneurship in emerging markets: Strategies for new venture creation in uncertain institutional contexts. Management International Review, 51(1), 23-39.

Tsai, W., \& Ghoshal, S. (1998). Social capital and value creation: The role of intrafirm networks. Academy of Management Journal, 41(4), 464-476.

Uzzi, B. (1997). Social structure and competition in interfirm networks: The paradox of embeddedness. Administrative Science Quarterly, 42(1), 35-67.

Vaccaro, A., \& Palazzo, G. (2015). Values against violence: Institutional change in societies dominated by organized crime. Academy of Management Journal, 58(4), 1075-1101.

Vargo, S. L., Wieland, H., \& Akaka, M. A. (2015). Innovation through institutionalization: A service ecosystems perspective. Industrial Marketing Management, 44, 63-72.

Venkataraman, H., Vermeulen, P., Raaijmakers, A., \& Mair, J. (2016). Market meet community: Institutional logics as strategic resources for development work. Organization Studies, 37(5), 709-733.

Weick, K. E. (1995). Sensemaking in organizations. Thousand Oaks, CA: Sage.

Whitehead, T. (2005). Basic classical ethnographic research methods.

Zilber, T. B. (2002). Institutionalization as an interplay between actions, meanings, and actors: The case of a rape crisis center in Israel. Academy of Management Journal, 45(1), 234-254.

Nicola Mountford is a Lecturer in Management at Maynooth University School of Business and completed her PhD in the Smurfit School of Business, University College Dublin, Ireland. Nicola's research focuses on the re-organization of public good markets such as healthcare. She is particularly interested in the roles played by public actors and inter-organizational networks in evolving markets. She has been a Fulbright scholar in eHealth and has published articles on this issue in journals including Organization Studies. 